\title{
Pengaruh Masa Kerja, Lama Paparan Terhadap Gejala Gangguan Fungsi Paru Pada pekerja garment UD. Surabaya Kabupaten Jember (Studi di UD. Surabaya Kabupaten Jember)
}

\author{
The Effect Of Tenure, Length Of Exposure on Pulmonary Function Disorder on Garment Workers At \\ UD. Surabaya JemberRegency
}

\author{
Mayang Sari Eka Sriwahyuningsih ${ }^{1}$, Ancah Caesarina Novi Marchianti ${ }^{2}$, Hadi Prayitno ${ }^{3}$ \\ ${ }^{\prime}$ Mahasiswa Pascasarjana Ilmu Kesehatan Masyarakat Universitas Jember \\ ${ }^{2}$ Fakultas Kedokteran Univeristas Jember \\ ${ }^{3}$ Fakultas Ilmu Sosial dan Politik Universitas Jember \\ Email: mayangahmadi94@gmail.com
}

\begin{abstract}
One of the vital organs in humans is the lungs. Disorders that occur in the lungs will make the body's metabolism unbalanced and can reduce the quality of the human body. Pulmonary function disorders do not only occur in developed countries but in developing countries such as Indonesia. Lung function disorders can be caused by occupations with high dust exposure such as the Garment Industry.The purpose of this study was to analyze the effect of work tenure, length of exposure to symptoms of lung function disorders in garment workers in UD Surabaya, Jember Regency. The data used are primary data obtained from questionnaires of 108 worker respondents. The analysis tool uses regression of weight techniques using AMOS software. The results of instrument testing conclude that all variables are valid and reliable as data collection tools. The results of data analysis indicate that: 1) tenure has a positive effect on symptoms of lung function disorders in garment workers. 2) the length of exposure has a positive effect on symptoms of lung function disorders in garment workers. 3) Most of UD garment workers. Surabaya, Jember Regency has or is experiencing symptoms of lung function disorders in the form of coughing and chest tightness / breathing.
\end{abstract}

Kata Kunci: Lung function disorders, working period, length of exposure.

\begin{abstract}
ABSTRAK. One of the vital organs in humans is the lungs. Disorders that occur in the lungs will make the body's metabolism unbalanced and can reduce the quality of the human body. Pulmonary function disorders do not only occur in developed countries but in developing countries such as Indonesia. Lung function disorders can be caused by occupations with high dust exposure such as the Garment Industry.The purpose of this study was to analyze the effect of work tenure, length of exposure to symptoms of lung function disorders in garment workers in UD Surabaya, Jember Regency. The data used are primary data obtained from questionnaires of 108 worker respondents. The analysis tool uses regression of weight techniques using AMOS software. The results of instrument testing conclude that all variables are valid and reliable as data collection tools. The results of data analysis indicate that: 1) tenure has a positive effect on symptoms of lung function disorders in garment workers. 2) the length of exposure has a positive effect on symptoms of lung function disorders in garment workers. 3) Most of UD garment workers. Surabaya, Jember Regency has or is experiencing symptoms of lung function disorders in the form of coughing and chest tightness / breathing.
\end{abstract}

Keywords: Lung function disorders, working period, length of exposure.

\section{Pendahuluan}

Salah satu sektor yang berkembang pesat adalah industri tekstil dan garment. Industri tekstil. Industri garment merupakan salah satu industri yang menyerap tenaga kerja dengan jumlah banyak serta menduduki peringkat ke tiga sebagai sektor maufaktur terbesar di Indonesia, serta diperkirakan masih bisa berkembang sekitar 4\% pada tahun 2019 [1].

Keberhasilan di sebuah industriharusnya didukung oleh kesehatan kerja yang dapat mengatasi berbagai masalah penyakit yang diakibat dari pekerjaan untuk meningkatkan kesejahteraan dan produktifitas kerja. Hal ini sesuai dengan Undang-Undang Kesehatan dan keselamatan kerja No.1 
tahun 1970 dan di perkuat oleh Undang-Undang No. 36 tahun 2009 tentang kesehata kerja, pasal 164-165 yang menyatakan bahwa semua tempat kerja wajib menerapkan upaya kesehatan kerja baik pada sektor informal maupun informal. Kementerian kesehatan RI tahun 2016 mengatakan bahwa pekerja akan memiliki risiko tinggi mengalami berbagai masalah kesehatan yang diakibatkan dari proses kerja, lingkungan kerja, dan prilaku selama bekerja sehingga memliki potensi terjadi penyakit akibat kerja (PAK). Parikel kabut, uap dan gas yang terhidup pada saat bekerja akan menyebakan penyakit gaggua fungsi paru. Dari data yang di peroleh RISKESDAS 2007 didapatkan 10 penyakit penyebab kematian di Indonesia PPOK menduduki peringkat ke 6 dengan pervalensi 3,7\%. Beberapa faktor yang memepengaruhi gejala gangguan fungsi paru diantaranya gejala gangguan fungsi paru akibat debu bahan kimia. Faktor lain yang mempengaruhi gejala gangguan fungsi paru adalah kontak pajanan (masa kerja dan lamapapran) [2].

Beberapa penelitian terkait dengan penyakit akibat kerja telah dilakukan, salah satunya yang dilakukan oleh Penelitian yang di lakukan oleh Sreesupria dan Panka (2013) terkait masalah kesehatan dan faktor risiko yang terjadi pada pekerja garmentmenunjukkan hasil gangguan pernafasan masuk dalam penyakit yang banyak terjadi dengan persentasi $31,3 \%$, disebabkan serat yang sering di abaikan, menghirup berlebihan jumlah parikel debu membuat pekerja lebih rentan terhadap penyakit paru.Gejala yang di keluhkan adalah batuk dahak dengan gejala yang paling lazim di laporkan sekitar $17,1 \%$, di ikuti oleh batuk 15,8\%, sesak nafas $11,6 \%$ dan mengi 7,8\%. Mayoritas pekerja, 66,7\%-76,9\% menderita batuk dahak selama empat hari atau lebih [3].

UD. Surabaya merupakan industri informal yang bergerak di bidang garment yang membuat pakaian jadi di kota Jember. Berdasarkanhasil studi pendahuluanUD. Surabaya memiliki beberapa proses pengerjaan diantaranya, memotong bahan, menjahit, dan bagian finishing. Semua pengerjaan di lakukan di dalam ruangan dengan jumlah pekerja sebanyak 140 orang (100 bagian menjahit, 10 orang bagian potong dan 30 finishing). Pekerja telah bekerja kurang lebih 5-15 tahun dengan 9 jam kerja rata-rata perhari tanpa ada hari libur. Sebanyak 5 dari 10 pekerja yang diwawancarai secara acak, mengatakan bahwa mereka mengalami gangguan pernafasan seperti sesak pada saat bekerja, dan 3 orang pekerja menderita gejala gangguan fungsi paru setelah 10 tahun bekerja. Berdasarkan latar belakang diatas, masalah yang dapat dirumuskan adalah Bagaimana gejala gangguan fungsi paru dan determinannya pada pekerja garment di UD. Surabaya Kabupaten Jember.Pendahuluan menjelaskan latar belakang masalah yang diselesaikan, masalah yang terkait dengan masalah diselesaikan, tinjauan penelitian yang sebelumnya dilakukan oleh peneliti lain yang relevan dengan penelitian yang dilakukan.

\section{Bahan dan Metode}

Penelitian ini merupakan penelitian kuantitatif dengan jenis penelitian yang digunakan adalah survey analitik yaitu suatu penlitian yang dilaukan tanpa melaukan interverensi terhadap subjek atau penelitian non eksperimental yang bertujuan untuk menjelaskan suatu keadaan atau situasi dengan disain cross sectional, dimana variabel bebas dan variabel terikat yang terjadi pada objek penelitian dasar diukur dan dikumpulkan pada waktu yang bersamaan.

Lokasi penelitian ini di UD Surabaya kecamatan Rambipuji Kabupaten Jember. Populasi dalam penelitian ini adalah seluruh pekerja garment dengan jumlah sampel sebanyak 108 responden.

Penelitian ini menggunakan data primer yang berasal dari responden yang mengisi kuisioner yang dibagikan oleh peneliti. Analisis yang digunakan adalah teknik regressionof weight menggunakan software AMOS untuk meneliti seberapa besar pengaruh dua variabel bebas terhadap variabel terikat dilihat dari nilai koefisien determinasi atau estimate.

\section{Hasil dan Pembahasan}

Distribusi Frekuensi Faktor Agent Garment UD. Surabaya Kabupaten Jember

\begin{tabular}{|c|c|c|c|c|c|}
\hline NO & $\begin{array}{c}\text { TEST } \\
\text { DESCRIPTIO } \\
\mathbf{N}\end{array}$ & $\begin{array}{c}\text { SAMPLE } \\
\text { RESUL } \\
\mathbf{T}\end{array}$ & $\begin{array}{c}\text { REGULA } \\
\text { TORY } \\
\text { LIMIT * }\end{array}$ & UNIT & METHOD \\
\hline & $\begin{array}{l}\text { Indoor Air } \\
\text { Quality: }\end{array}$ & & & & \\
\hline 1 & $\begin{array}{l}\text { Formaldehyde, } \\
\mathrm{HCHO}^{\#}\end{array}$ & $<1$ & - & $\mu \mathrm{g} / \mathrm{Nm}^{3}$ & $\begin{array}{l}\text { IKM-EI-SML-17 } \\
\text { (Direct Reading) }\end{array}$ \\
\hline 2 & $\begin{array}{l}\text { Carbon Dioxide, } \\
\mathrm{CO}_{2}^{\#}\end{array}$ & 432 & 5000 & ppm & Electrochemichal \\
\hline 3 & $\begin{array}{l}\text { Carbon } \\
\text { Monoxide, } \mathrm{CO}\end{array}$ & 2.0 & 25 & $\mathrm{ppm}$ & NIOSH 6604:1996 \\
\hline 4 & Oxidant, $\mathrm{O}_{3}$ & $<0.007$ & 0.08 & $\mathrm{ppm}$ & $\begin{array}{c}\text { IKM-EI-SML-24 } \\
\text { (Spectrophotometr } \\
y)\end{array}$ \\
\hline 5 & Dust & 0.34 & 10 & $\mathrm{mg} / \mathrm{m}^{3}$ & SNI 16-7058-2004 \\
\hline 6 & $\begin{array}{l}\text { Total Viable } \\
\text { Bacterial Count } \\
\end{array}$ & 70 & 700 & $\begin{array}{c}\mathrm{CFU} / \mathrm{c} \\
\mathrm{m}^{3}\end{array}$ & $\begin{array}{c}\text { IKM-EI-SML-5 } \\
\text { Point 3.3.1 } \\
\text { (Impinger ) } \\
\end{array}$ \\
\hline 7 & VOCs & 0.01 & - & $\mathrm{ppm}$ & $\begin{array}{c}\text { IKM-EI-SML- } \\
17 \text { (Direct } \\
\text { Reading) }\end{array}$ \\
\hline
\end{tabular}

Tabel 1 Area Pemotongan UD. Surabya

Tabel 2 area jahit dan finishing UD. Surabaya

\begin{tabular}{llrc}
\multicolumn{4}{c}{ Meteorology Data } \\
\hline 1 & Temperature & $30.4-34.8$ & $0_{\mathrm{C}}$ \\
\hline 2 & Relative Humidity & $51.4-68.5$ & $\%$ \\
\hline
\end{tabular}

Tabel 3 Area Jahit Dan Finishing UD. Surabaya

\begin{tabular}{rrrr}
\hline \multicolumn{5}{c}{ Meteorology Data } \\
\hline 1 & Temperature & $27.1-28.9$ & ${ }^{\circ} \mathrm{C}$ \\
\hline
\end{tabular}




\begin{tabular}{l}
\hline 2 Relative Humidity \\
\hline Berdasarkan tabel .3 suhu pada area pemotongan \\
UD. Surabaya adalah sekitar $30,4-34,8^{\circ} \mathrm{C}$ dan kelembaban \\
sekitar $52,4-68,5 \%$. Sedangkan pada tabel 4 suhu pada area \\
jahit dan fihishing $27,1-28,9{ }^{\circ} \mathrm{C}$, dan kelembaban sekitar \\
$70,1-78,3 \%$
\end{tabular}

\section{Distibusi Frekuensi Gejala Gangguan Fungsi Paru pada} Pekerja Garment UD. Surabaya Kabupaten Jember Tabel 4 Distribusi Jumlah Kontak Pajanan Pada Pekerja UD. Surabaya

\begin{tabular}{|c|c|c|c|}
\hline No & Kategori & & \\
\hline \multirow[t]{4}{*}{1.} & Lama paparan & Jumlah & $\%$ \\
\hline & Kurang dari 8 jam & 12 & 11,1 \\
\hline & Lebih dari 8 jam & 96 & 88.9 \\
\hline & Total & 108 & 100 \\
\hline \multirow[t]{4}{*}{2.} & Masa kerja & Jumlah & $\%$ \\
\hline & Kurang dari 5 tahun & 25 & 23,1 \\
\hline & Lebih dari 5 tahun & 83 & 76,9 \\
\hline & Total & 108 & 100 \\
\hline
\end{tabular}

Berdasarkan tabel 3.6 menunjukkan bahwa mayoritas pekerja UD. Surabaya memiliki paparan atau konta pajanan lebih dari 8 jam dan sebagian besar pekerja memiliki masa kerja selama 5 tahun.

Distribusi frekuensi gejalan gangguan fungsi paru pada pekerja garment UD. Surabaya Kbeupaten Jember Tabel 5 distribusi frekuensi gejala gangguan fungsi paru pada pekerja garment UD. Surabya

\begin{tabular}{|c|c|c|c|}
\hline No & Kategori & & \\
\hline \multirow[t]{4}{*}{1.} & Batuk & Jumlah & $\%$ \\
\hline & Tidak & 53 & 49,1 \\
\hline & $\mathrm{Ya}$ & 55 & 50,9 \\
\hline & Total & 108 & 100 \\
\hline \multirow[t]{4}{*}{2.} & Berdahak & Jumlah & $\%$ \\
\hline & Tidak & 69 & 63,9 \\
\hline & $\mathrm{Ya}$ & 39 & 36,1 \\
\hline & Total & 108 & 100 \\
\hline \multirow[t]{4}{*}{3.} & Batuk berdahak & Jumlah & $\%$ \\
\hline & Tidak & 89 & 82,4 \\
\hline & $\mathrm{Ya}$ & 19 & 17,6 \\
\hline & Total & 108 & 100 \\
\hline \multirow[t]{4}{*}{4.} & Sesak dada/ nafas & Jumlah & $\%$ \\
\hline & Tidak & 36 & 33,3 \\
\hline & $\mathrm{Ya}$ & 72 & 66,7 \\
\hline & Total & 108 & 100 \\
\hline
\end{tabular}

\begin{tabular}{cccc}
5. & Riwayat penyakit dada & Jumlah & $\%$ \\
\hline Tidak & 103 & 95,4 \\
\hline Ya & 5 & 4,6 \\
\hline Total & 108 & 100
\end{tabular}

Berdasarkan tabel tabel 6 gejala yang paling dominan dirasakan oleh para pekerja garment UD. Surabaya adalah sesak dada/nafas sevanyak 72 orang dengen persentase 66,7 .

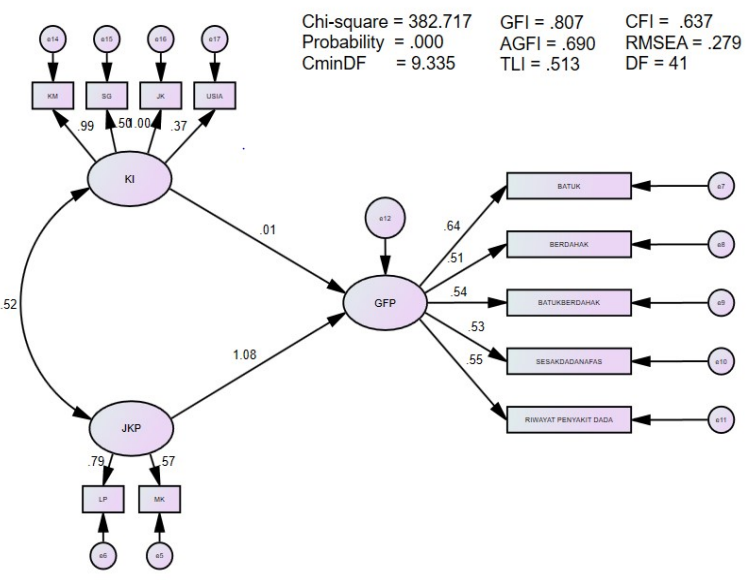

Pengaruh jumlah kontak pajanan terhadap gejala gangguan fungsi paru pada pekerja garment UD. Surabaya kabupaten jember

Hasil penelitian ini menunjukkan bahwa jumlah kontak pajanan (masa kerja dan lamapaparan) memiliki pengaruh positif terhadap gejala gangguan fungsi paru pada pekerja garment UD. Surabaya Kabupaten Jember. Indikator jumlah konta pajanan yang berpengaruh terhadap gejala gangguan fungsi paru adalah lama paparan dan masa kerja. Pemgaruh yang bersifat positif menunjukkan adanya pengaruh sejajar. Artinya semakin banyak dan semain lama kontak pajanan pekerja garment maka pekerja tersebut cenderung semakin atau mengalami gejala gangguan fungsi paru. Hasil penelitian ini serupa dengan penelitaian yang dilakukan Helmy (2019) mengemukakan bahwa lama paparan denagn debu berpengaruh terhadap status faal paru pekerja. Pekerja yang mengalami lama paparan lebih lama maka akan lebih beresiko mengalami gangguan fungsi paru (4). Penelitian yang dilakukan Nafisa et al. (2016) menunjukkan adanya hubungan antara masa kerja dengan gangguan fungsi paru. Pekerja denagn masa kerja lebih dari 5 tahun memiliki resiko 13,5 kali lebih besar untuk mengalami gangguan fusngsi paru di bandingkan denagn pekerja dengan masa kerja kurang dari 5 tahun (5). Dimana penelitian ini sesuai dengan penelitian yang di lakukan di UD. Surabaya Kabupaten Jember. Sedangka untuk lama paparan dalam penelitian yang di lakukan oleh Nafisa et al. (2016) menyatakan tidak ada pengaruh signifikan dan hasil ini berbanding terbalik dengan hadil penelitian di UD. Surabaya kabupaten jember. Dalam penelitian Ardam (2015) juga menyatakan tidak adahubunga antara lama 
paparan dengan gangguan fungdi paru. Dimana terdapat faktor lain selan kurun waktu 8 jam atau lebih perhari yang menyebabkan gangguan fungsi paru (6).

Dalam hal ini indikator kontak pajanan (masa kerja dan lama paparan memliki pengaruh positif terhdap gajala ganggua funsgi paru meskipun kondisi lingkungan berada di nila ambag batas. Kemungkinan hal ini terjadi dikarenakan padasaat melakukan penalitian tida maksimal, sebab pada pada saat penlitian dilakukan kondisi garment berada pada masapandemi penyakit sehingga pekerja tida bayak menghasilkan pakain jadi. Faktor lain adalah di waktu pengukuran yag seharusnya dilakukan selama jam kerja (10 jam) namum hari pertama pengukuran pada ruang pemotongan haya di lakuka 4 jam pengukuran dan tidak dilakukan berulang. Dala arti pengukura hanyadilaukan 1 kali .

\section{Kesimpulan}

Berdasarkan hasil penelitian yang telah dilakukan, maka dapat diperoleh beberapa kesimpulan sebagai berikut:

a. Ketujuh komponen kualitas udara dalam ruangan di area pemotongan dan di area jahit dan finishing UD. Surabaya Kabupaten Jember menunjukkan hasil dibawah nilai ambang batas

b. Suhu pada area pemotongan UD. Surabaya Kabupaten Jember adalah sekitar 30,4-34,8 oC dengan kelembaban sekitar 51,4-68,5\%.

c. Sebagian besar pekerja UD. SurabayaKabupaten Jember berusia produktif (17-47 tahun), berjenis kelamin perempuan, memiliki kebiasaan tidak merokok, dan memiliki status gizi kurang.

d. Mayoritas pekerja memiliki masa kerja selama lebih dari 5 tahun.

e. Sebagian besar pekerja garment UD. Surabaya Kabupaten Jember memiliki atau mengalami gejala gangguan fungsi paru berupa batuk dan sesak dada/nafas.

\section{Referensi}

[1] Kementrian perindustrian Republik Indonesia. 2018. Analisis Perkembangan Industri Edisi III-2018. Jakarta Selatan. PUSDATIN KEMENPERIN

[2] Kemenkes RI No. 1077/Menkes/per/v/2011 Tentang Pedoman Penyehatan Udara Dalam Rumah. Menteri Kesehatan. Jakarta

[3] Sreesupria P.R \& Pankaj B. Shah. 2018. Health problems and risk factors prevailing among garment workers in Tirupur, Tamil Nadu. International Journal of Community Medicine and Public Health Ravichandran SP et al. Int J Community Med Public Health. 2018 Jun;5(6):2400-2405.

https://www.ijcmph.com/index.php/ijcmph/article/view/2888 (diakses pada tanggal 20 juni 2019)

[4] Helmy, R. 2019. Hubungan Paparan Debu dan Karakteristik Individu dengan Status Faal Paru Pedagang di Sekitar Kawasan Industri Gresik Jurnal Kesehatan Lingkungan 2019; 11(2): 132-140

[5] Nafisa, R. S. F., Joko, T. dan Setiani, O. 2016. Hubungan Paparan Debu Kayu Di Lingkungan Kerja Terhadap Gangguan Fungsi Paru
Pada Pekerja Di PT. Arumbai Kasembadan, Banyumas. Jurnal Kesehatan Masyarakat 2016; 4(5): 178-1

[6] Ardam, K. A. Y. 2015. Hubungan Paparan Debu Dan Lama Paparan Dengan Gangguan Faal Paru Pekerja Overhaul Power Plant. The Indonesian Journal of Occupational Safety and Health 2015; 4(2): $155-166$. 